ГАЛИНА РУСИН, кандидат педагогічних наук, доиент кафедри педагогіки початкової освіти, ДВНЗ "Прикарпатський національний університет імені Василя Стефаника" ORCID 0000-0001-9601-5466 grusyn@gmail.com

\title{
ФОРМУВАННЯ ЦІННІСНИХ ОРІЕНТАЦІЙ ОСОБИСТОСТІ ЗАСОБАМИ ЕТНОПЕДАГОГІКИ
}

\author{
HALYNA RUSYN, PhD in Education, Associate Professor, \\ Department of Pedagogy of Primary Education, Vasyl Stefanyc \\ Precarpathian National University (Ivano-Frankivsk, Ukraine)

\section{FORMATION OF VALUE ORIENTATIONS OF PERSONALITY BY MEANS OF ETHNOPEDAGOGY}

У статті розглянуто значення етнопедагогіки у процесі підготовки майбутніх учителів до педагогічної діяльності і досягнення ними високого рівня професійних якостей. Висвітлено проблему формування професіоналізму та національної свідомості майбутнього фахівця на засадах української етнопедагогіки. У роботі обгрунтовано потребу вирізнення етнопедагогічної компетентності фахівця в галузі освіти.

Ключові слова: ціннісні орієнтації молоді, професіоналізм учителя, етнопедагогічна компетентність, майбутній учитель.

Summary. The article deals with the importance of ethno-pedagogy in the process of preparing future teachers for pedagogical activity and achieving a high level of professional qualities. The problem of formation of professionalism and national consciousness of the future specialist on the principles of Ukrainian ethno-pedagogy is covered. The work substantiates the need to identify the ethno-pedagogical competence of a specialist in the field of education; possibilities of taking into account the ethno-pedagogical context of the teacher's professional skill in the process of forming a future teacher were demonstrated.

Key words: youth value orientations, professionalism of the teacher, ethnopedagogical competence, future teacher.

Мета: обгрунтувати важливість етнопедагогічної компетентності вчителя, встановити ії̈ взаємозв'язок з професійною майстерністю сучасного педагога.

(C) Г. Русин
Постановка проблеми в загальному вигляді. Серед актуальних завдань розвитку освіти в Україні- підвищення рівня професіоналізму педагогів, формування національної спрямованості, питання історії розвитку української етнопедагогіки тощо.

На значущості застосування ідей етнопедагогіки наголошує чимало науковців, котрі у своїх дослідженнях зосереджують увагуна необхідності використання під час навчального процесу таких методів і засобів навчання, які забезпечать повноправну участь студента у процесі його професійної підготовки в умовах співробітництва, формування самостійності й оригінальності мислення. Саме навчальний процес, побудований на принципах етнопедагогіки, сприятиме вихованню у майбутнього педагога не лише почугтя патріотизму, а і глибокої поваги до споконвічних традицій свого народу, професійної відповідальності, стійкого інтересу та постійного прагнення до власного професійно-педагогічного вдосконалення (Андрущеекко \& Табачук, 2005, с. 58-59).

Аналіз останніх досліджень i публікацій. Сутність, структуру і зміст педагогічної майстерності, особливості iii формування у майбутніх учителів, вихователів вивчали Н. Волкова, $\mathrm{H}$. Гузій, І. Зязюн, В. Семиченко, Н. Тарасевич, В. Чайка та інші. Компетентнісний підхід в освіті та його основні категорії охарактеризовано В. Байденком, О. Бермусом, Н. Бібік, О. Пометун, О. Савченко, А.Хуторським та іншими. Трактування різних видів професійнопедагогічної компетентності, специфіки організації процесу формування цього особистісного утворення висвітлювалось у працях О. Бігич, І. Зим- ньої, І. Зязюна, Н. Кузьміної, А. Маркової, В. Радула, С. Ракова, В. Сластьоніна, Л. Хоружої та багатьох інших науковців. Здобутки етнопедагогіки як науки аналізували у своїх працях Г. Волков, В. Кононенко, В. Кузь, Н. Лисенко, В. Мосіяшенко, С. Приступа, М. Стельмахович, О. Сухомлинська, С. Сявавко, Т. Усатенко, Г.Філіпчук, М. Хайруддінов. На важливості етнопедагогічної підготовки майбутнього вчителя та формуванні етнопедагогічної культури акцентували В. Ніколаєв, М. Харитонов.

Виклад основного матеріалу дослідження. Основи психолого-педагогічного підходу до проблем формування ціннісних орієнтацій молоді закладені упрацях таких видатних учених, як П. Блонський, Л. Виготський, О. Леонтьєв, А. Макаренко, В. Сухомлинський, С. Шацький та інших. Ними окреслені загальні шляхи, сформульовані вихідні положення, визначено основні умови формування ціннісних орієнтацій молоді. Починаючи 3 кінця 60-х років XX століття, у вітчизняній науці чітко визначилася тенденція до поступового підвищення інтересу до питання цінностей загалом і ціннісних орієнтацій зокрема (Б. Ананьєв, А. Архангельський, В.Водзінська, О. Дробницький, Ю.Жуков, Л. Федоров та ін.). Їхні напрацювання стали поштовхом доподальших наукових пошуків упсихолого-педагогічній науці 70-80-х років XX століття. Багатоаспектність і складність феномена "ціннісні орієнтації" зумовила різноманітність підходів до розкриття його сутності, функцій, структури, визначення основних видів.

Предметом досліджень науковці визначили: формування ціннісних орієнтацій молоді у процесі спілкування 
(М.Чорнобаєва), трудового виховання (А. Здравомислов), морального становлення особистості (З.Васильова, В. Сухомлинський), орієнтації молоді на естетичні цінності (Т. Губченко, Н. Красноярова, В. Курілов та ін.). Проблема цінностей і ціннісних орієнтацій знаходиться в центрі уваги і сьогодні. 3 огляду на реалії буття пріоритетного значення набула орієнтація молодого покоління на втілення в життя української національної ідеї, збереження і продовження української культурно-історичної традиції виховання. Саме $з$ цих позицій підходять до проблеми становлення і розвитку ціннісних орієнтацій такі вчені, як А. Бойко, О. Сухомлинська, В. Постовий, В. Кузь, Ю.Руденко, 3. Сергійчук та інші.

У даний час можемо констатувати про відсутність загальноприйнятого визначення терміна "цінності". Насамперед ідеться про все те, що може цінувати особистість, що є для неї значущим і важливим. У філософії, етиці, соціології цінностей вважаються продукт конкретних історичних умов суспільного життя. На кожному етапі розвитку суспільства створюються специфічний набір і структура цінностей, що сприяють перетворенню соціальних норм та ідеалів в особистісні принципи життєдіяльності завдяки тому, що переростають у внутрішні спонуки (мотиви) поведінки особистості.

Як зазначає I. Бех, "у вихованні особистості мірилом унормованості поведінки служить іï̈ відповідність соціальним нормам, тобто вимогам суспільства, до якого належить індивід. Звичайно, цивілізоване суспільство завжди гармонійно поєднує загальнолюдські й національні моральні норми - цінності, які й мусить свідомо привласнити людина" (Бех, 2003, с. 134).

Професіоналізм служить основою, надійним фундаментом для справжнього фахівця і водночас метою та вищою ланкою педагогічної праці. Зокрема, його можна трактувати як певний рівень майстерності, педагогічну творчість, ототожнювати 3 поняттям самоосвіта і самовиховання. Сугність професіоналізму розкривається як сукупність характеристик суб'єкта діяльності (Бойко, 2004).

Поняття "професіоналізм учителя" ми не знаходимо в довідково- енциклопедичній літературі. Тобто точного, конкретного визначення даного терміна немає. Тому ми послуговуємось дослідженнями названих вище науковців. Так, С. Вітвицька тлумачить професіоналізм як інтегровану якість, що передбачає високий рівень продуктивності праці і $є$ результатом довготривалої педагогічної діяльності (Вітвищька, 2003). Професіоналізм у педагогіці зводиться до здатності передбачати перебіг педагогічних процесів, їх наслідки, ураховуючи вплив багатьох обставин, умов та конкретних чинників, уважає I. Підласий. Отже, професіоналізм - це вміння мислити і діяти професійно (Григоренко, 2005 , с. 22-23). Професіоналізм учителя слід розглядати як соціально-педагогічне явище і як персоналізований психолого-педагогічний феномен. Згідно з твердженням Н. Гузій, поняття "професіоналізм", "педагогічний професіоналізм", "професіоналізм учителя" широко використовуються для позначення педагогічної праці високої якості і загалом розглядаються, поперше, як норма, зразок виконання педагогічної діяльності відповідно до сучасного рівня педагогічних знань i цінностей, що виступає суспільним регулятивним механізмом праці вчителя; по-друге, вища школа ідентифікується з підготовленістю, компетентністю, вправністю вчителя; по-третє,3 особливим ставленням педагога до виконання своїх обов'язків на рівні покликання, місії (Григоренко, 2005).

Надійним помічником та супутником на шляху досягнення педагогічного професіоналізму є етнопедагогіка. Саме вона здатна пробуджувати, розвивати, удосконалювати якості педагога, що так необхідні для виховання і навчання майбутніх поколінь. Загальнолюдські аспекти й елементи етнопедагогіки, іiі норми грунтуються на властивих для нашого суспільства зв'язках між людьми, на обов'язкових для суспільного виробництва і самого життя взаєминах. Етнопедагогіка досліджує можливості й ефективні шляхи реалізації прогресивних педагогічних ідей народу в сучасній науково-педагогічній практиці, способи встановлення контактів народної педагогічної мудрості 3 педагогічною наукою; аналізує педагогічне значення явищ народного життя і визначає їх відповідність сучасним завданням виховання (Бойко, 2004).

Формування гармонійно розвиненої особистості відбувається на основі засвоєння майбутнім педагогом історично надбаних рідним народом знань, етнічних норм у таких сферах духовності, як народний світогляд, народна філософія, народна ідеологія, народна мораль, етика, народна естетика тощо. Провідними принципами етнопедагогікиє природовідповідність, культуровідповідність, єдність навчання і виховання, зв'язок навчання з працею, гуманізм, національне виховання та інше (Мосіяменко, 2005).

Одним 3 основних компонентів у професійному становленні майбутнього вчителя є націонсоціальної практики, спрямованих на організацію життєдіяльності підростаючих поколінь, у процесі якої засвоюється духовна і матеріальна культура нації, формується національна свідомість і досягається духовна єдність поколінь (Вишневський, 1996). Нальне виховання-це історично зумовлена і створена самим народом сукупність ідеалів, поглядів, переконань, традицій, звичаїв та інших форм аціональне виховання - це виховання студентів у дусі українського виховного ідеалу на багатовікових традиціях. Воно грунтується на засадах родинного виховання, ідеях і засобах народної педагогіки, наукової педагогічної думки, що уособлюють кращі зразки виховної мудрості народу. Основні положення національного виховання - гуманізм, демократизм, народність, природовідповідність, виховання у праці, самодіяльність студентів (Стельмахович, 1985). У навчально-виховній роботі майбугній педагог повинен ураховувати, що національний характер і темперамент багатьох українців мають деякі нашарування, які історично не притаманні їм і виникли під впливом чужорідних факторів, політичних віянь і установок, ідеологічних догм, привнесених ззовні.

Історична місія батьків, педагогів, усієї громадськості- сприяти створенню таких суспільно-політичних умов і виробляти у студентів таку громадську позицію, які не руйнували б національний характер, а всіляко його підтримували, зберігали і розвивали (Зязюн, 2004). Надійним фундаментом, на якому успішно формується національна свідомість українців, $є$ історична пам'ять, безцінний досвід, що зберігає кожну сторінку життя, боротьби рідного народу за соціальні, політичні і національні права на всіх етапах його розвитку (Чорна, 1994). Необхідно зазначити, що відсутність національної свідомості нерідко спричиняє оманливе відчуття "меншовартості", "другорядності" рідної мови, культури, урешті-решт, самого себе, народжує комплекс національної і громадської неповноцінності.

Коли духовні цінності рідного народу забуваються, штучно звужуються (з різних причин - політичних, ідеологічних тощо), національна система 
виховання гальмується і занепадає. Унаслідок цього в суспільстві поширюються як соціальна хвороба, моральні "пустоцвіти", духовні безбатченки. Виходячи 3 такої ситуації може бути організація широкої національно-просвітницької діяльності, повноцінного науково обгрунтованого національного виховання, яке формує в особистості найкращі людські чесноти та національну свідомість (Стельмахович, 1985). Національна свідомість закладається навколо усвідомлення причетності людини до роду і соціальної групи, існуючих як факт існування певної культурної системи. Національне усвідомлення - це раціональне, інтелектуальне прагнення завбачати перспективи життя народу в системі його самозабезпечення. Тому поняття української перспективи адекватне національній свідомості народу (Мосіяшенко, 2005).

У розвитку національної свідомості О. Вишневський виділяє три окремі етапи: перший - етап раннього етнічного самоусвідомлення. Він починається 3 раннього періоду життя в сім'ї, маминої колискової, бабусиної казки, народних звичаїв та обрядів, народної пісні. У сім'ї та школі діти вчаться поважати ідеал свого народу, шанобливо ставитись до видатних українських історичних і культурних діячів. У ранньому віці дитина засвоює культуру рідного дому, сім'ï, предків, рідного села, міста.

Другий етап - етап національнополітичної свідомості, що припадає переважно на підлітковий вік і передбачає усвідомлення себе як частки нації серед інших націй. У цей час відновлюється історична пам'ять, формується почугтя національної гідності. До факторів відродження історичної пам'яті належить все, що відбиває історичний шлях нашого народу, його боротьбуза волю. Етап національно-політичного усвідомлення пов'язаний 3 громадською активністю. Хлопець чи дівчина усвідомлює політичну ситуацію, у якій живе та розвивається нація.

Третій етап - етап громадського самоусвідомлення того, що бути націоналістом - значить любити свою націю, бути патріотом - значить любить Батьківщину. Тут вся багатогранна діяльність громадянина концентрується в загальнонаціональних завданнях, проблемах національної свідомості, стимулює самовіддану працю на користь Україні (Вишневський, 2006). Етнопедагогіка через навчання і виховання молоді відтворює, продовжує і розвиває у кожному наступному поколінні український народ.

На думку науковців, саме професійна компетентність у структурі педагогічної майстерності і педагогічного професіоналізму "забезпечує цілісність системи, що самоорганізовується" (Григоренко, 2005, с. 30). Складником професійної компетентності вчителя виступає педагогічна компетентність, яку варто розглядати як єдність різних іiі видів. Зважаючи на залежність педагогічної компетентності від професійної культури педагога, у визначенні першої ми керуємось ідеєю іï взаємозв'язку з різними сферами культури. Багатогранність наукового педагогічного знання, що проектується на професійну компетентність педагога, визначають багатоаспектність педагогічної компетентності та педагогічної майстерності в цілому.

Соціально-економічні зміни в суспільстві, тенденції гуманітарної конверсії загострили потребу в діяльності педагога, спроможного осмислити закономірності соціалізації особистості 3 огляду на традиції та трансформацію соціокультурного простору, організувати культуровідповідне освітнє середовище, усі компоненти якого наповнені людським сенсом, допомогти молоді самореалізуватися, виявити власний творчий потенціал у всіх сферах життедіяльності.

Інтеграція української системи вищої професійної освіти до світового освітнього простору, потреба в розв'язанні глобальних проблем входження людини в соціальний світ, що пов'язані 3 тенденціями до етнічного відродження, інтенсифікації міжетнічних контактів, адаптації людини в багатонаціональному світі, зумовлюють необхідність підготовки компетентного фахівця в галузі освіти, що є носієм своєї національної культури та спроможний ураховувати у професійній діяльності надбання різних народів. У цьому контексті актуальним виявляється етнопедагогічний аспект педагогічної майстерності вчителя, який знаходить відображення у такому різновиді професійної компетентності педагога, як етнопедагогічна компетентність.

Етнопедагогічна компетентність фахівця в галузі освіти актуалізована етносоціальною структурою українського суспільства, до якого згідно з офіційними даними входять представники понад 130 етносів. Україну за складом населення відносять до держав 3 поліетнічним складом населення (Євmyx, 2004, с. 8).
Етнопедагогічну компетентність фахівця в галузі освіти в дослідженні трактовано як різновид професійної компетентності педагога, особистісне утворення, що виявляє засвоєння фахівцем досвіду пізнавальної діяльності в галузі етнопедагогіки, емоційноціннісних відношень щодо нього, досвіду творчої діяльності в оперуванні етнопедагогічною інформацією, певного досвіду розв'язання педагогічних проблем, пов'язаних із застосуванням на теоретичному та практичному рівнях надбань етнопедагогічної культури.

Відповідно, етнопедагогічна компетентність передбачає опанування педагогом системи знань про етнос, народні погляди на дитину, їі вікову періодизацію, родину та особливості родинного виховання дітей; мету, завдання, принципи, правила, методи, засоби, прийоми, форми навчання і виховання юних поколінь; особливості виховання патріота та формування в молоді зорієнтованості на національне й загальнолюдське; педагогіку народного календаря та специфіку виховання засобами різних видів народного мистецтва; народні погляди на ідеали дорослого, вихователя, учителя, їхні обов'язки перед дітьми, підлітками й молоддю тощо (Ткаченко, 2013, с. 30 31).

У визначенні етнопедагогічної компетентності вчителя ми дотримуємось позиції Г. Н. Волкова про вивчення в межах етнопедагогіки педагогічних культур різних народів (Волкова, 2007, c. 8), що набуває особливої цінності у становленні педагогічної майстерності фахівця. У процесі оволодіння етнопедагогічною компетентністю майбугній фахівець угалузі освіти знайомиться 3 різними педагогічними культурами, виховними системами народів світу, які різняться виховними ідеалами, низкою принципів навчання і виховання, формами, засобами, методами та прийомами педагогічного впливу, поглядами на особистість вихователя, учителя, співвідношенням прогресивних та пережиткових ідей і явищ з позиції сучасної офіційної педагогіки. Для грамотного опрацювання етнопедагогічної інформації важливо підходити до неї $з$ позицій історичного аналізу, з урахуванням здобутків етнопсихології, етногеографії, релігієзнавства, мистецтвознавства. Такі особливості пізнавального процесу стимулюють розвиток педагогічного мислення, підвищують рівень усвідомлення педагогічних категорій, конкретних закономірностей $\mathrm{i}$ 
принципів, вагомості певних чинників для ефективності організації педагогічного процесу, що сприяє удосконаленню загальної педагогічної компетентності.

Саме "спрямованість на особистість іншої людини, утвердження словом і працею найвищих духовних цінностей, моральних норм поведінки і стосунків", які культивуються у більшості народів світу, становлять важливий елемент педагогічної майстерності, що називають гуманістичною спрямованістю діяльності педагога (Зязюн, 2004, с. 30-31). Удосконалення такої якості відбувається під час вивчення етнопедагогіки і шляхом усвідомлення значення обраної професії для повноцінного розвитку дитини, формування в майбугніх фахівців певної професійної позиції, готовності до самовдосконалення, організації фахової діяльності з урахуванням здобутків етнопедагогічної культури.

Учитель зі сформованою етнопедагогічною компетентністю на основі аналізу багатовікового народного педагогічного досвіду, осмислення явищ усфері освіти, виявлення традиційності і ступеня новизни конкретних педагогічних систем та їх елементів здатен реалізувати вимоги певних принципів в умовах діалогічного педагогічного спілкування, запропонувати власні інновації та втілити їх у життя, виходячи з етнічної приналежності певного контингенту школярів, вихованців, стереотипів виховних впливів їхніх батьків, творчо застосувати етнопедагогічний матеріал (народні задачі, жарти, примовки, прислів'я, ігри, пісні, твори декоративно-ужиткового мистецтва тощо) під час різних форм навчання i виховання.

Аналіз народних поглядів на вчителя, його майстерність націлюють на виокремлення особистісних якостей, які вважались ціннісними для вихователя, наставника в багатьох країнах світу(наприклад, відповідальності, доброзичливості, толерантності, спостережливості, національної самосвідомості), на розуміння важливості підвищення власної ерудиції, сприяють спрямованості майбутніх фахівців на розвиток певних груп педагогічних здібностей, удосконалення умінь педагогічної техніки (володіння своєю мімікою, пантомімікою, голосом, емоціями, здатність впливати на групу людей 3 метою стимулювання їхньої діяльності, організації різних форм виховної роботи тощо).

Для студентів Педагогічного фа- культету Прикарпатського національного університету імені Василя Стефаника ми запропонували провести "Коло моїх цінностей і духовності як можливість черпати ресурси", розроблене Н. Лебідь, кандидатом психологічних наук Київського університету імені Бориса Грінченка.

Коло цінностей - це Коло, яке першим проводиться у групі має на меті сформувати спільні уявлення про цінності, сприяти встановленню атмосфери довіри.

Під базовими цінностями розуміємо основні життєві сенси, якими індивіди, включені в різні форми соціальної активності, керуються у своєму повсякденному житті; сенси, які значною мірою визначають ставлення індивідів до дійсності, що оточує їх, i детермінують основні моделі соціальної поведінки.

Досліджуваним було запропоновано бланк цієї методики, де зазначені цінності розташовувались в алфавітному порядку. В інструкції студентам пояснювали, що ці цінності потрібно переструктурувати так, щоб вони розміщувались за ступенем значущості для кожного респондента. Досліджувані мали прописати бали від одного до десяти: один бал - цінність, яку студент ставить для себе на перше місце; два бали - на друге тощо.

Отже, студенти визначили "Коло цінностей" за такими напрямами і в такій послідовності:

1. Сім'я.

2. Kap'єpa.

3. Матеріальне забезпечення.

4. Здоров'я.

5. Взаємини з рідними.

6. Взаємини з оточуючими.

7. Пізнання світогляду (подорожі).

8. Культурний розвиток.

9. Самовдосконалення.

10. Духовні цінності.

Найбільш значущими виявилися такі цінності: здоров'я та спорт - 82\%; оточення і друзі - $81 \%$; любов, сім'я $80 \%$; кар'єра та бізнес-71\%.

Згідно $з$ дослідженнями, основні пріоритети сучасної молоді - це добробут, кар'єра, фінансова незалежність від батьків, сім'я, свобода.

У ході експерименту такі категорії, як цінності вивчались за допомогою відповіді на запитання: "Що, на вашу думку, представляє найбільшу цінність у житті?" "Гарне життя-це...". Аналіз отриманих результатів наштовхує нас на різні узагальнення.

Таким чином, найвартіснішим для молодій є здоров'я. Слід зауважити, що дівчата більшою мірою орієнтовані на сімейні цінності; важливо добре заробляти і самовдосконалюватись. Для них здоров'я більш важливе, ніж для хлопців. При цьому чесна праця і повага оточуючих мали місце в кінці списку. Як ми бачимо, сьогодні переважають особистісні пріоритети - сім'я, друзі, житлові умови, робота, власне здоров'я. Це важлива тенденція, що характеризує зміни ціннісних орієнтацій студентів, тобто йдеться про перевагу індивідуалізму, акцент на особистісно сімейних інтересах.

Отже, в останнє десятиліття уструктурі життєвих пріоритетів молоді стався перехід від спрямованості на самореалізацію й альтруїстичні цінності до націленості на розваги, особисте благополуччя. У сучасних студентів спостерігається тенденція до переорієнтації на індивідуально та особистісно значущі цінності. Переважна більшість молоді на передній план ставить матеріальні цінності; цінності, які мають значення лише в теперішньому часі $\mathrm{i}$ лише для них самих - цінності найближчої перспективи.

Для теперішньої молоді характерні прагнення до самоствердження і бажання бути такими, що визнані оточенням. Думка про вигідне утвердження в житті і необхідність підготовки до цього зайняла головне місце у свідомості студентів, що свідчить про очевидну потребу в життєвому і професійному самовизначенні, заможності та насолоді від життя.

Водночас більшість студентів обирає прагматичну орієнтацію, пріоритет матеріальних цінностей над духовними. Проте багато 3 них шукають можливість поєднати духовні та прагматичні цінності. Їх можна назвати "культурними прагматиками". Саме ця категорія молоді вимагає особливої уваги іє резервом духовності при створенні певних умов їх подальшого розвитку. 3 точки зору виховання йдеться про те, що в центрі уваги повинна бути актуалізована (максимально розвинута) особистість, котра через трансформовані, "окультурені" прагматичні цінності прямує до духовного зростання, будує ієрархічно правильну систему цінностей, де на першому місці знаходяться усе ж духовні вартісності (Григоренко, 2005).

Висновки та перспективи подальших досліджень. Таким чином, ціннісні орієнтації-це відображення у свідомості людини цінностей, визнаних нею як стратегічні життєві цілі і загальні 
світоглядні орієнтири. Насамперед маємо на увазі ідеологічні, політичні, моральні, естетичні та інші підстави для оцінювання суб'єктом навколишньої дійсності, орієнтації в ній; спосіб диференціації об'єктів індивідом за їх значимістю. Слід наголосити, що правильні цінності будуть сформовані тільки за умови, коли молодь виховуватиметься на традиціях та звичаях українського народу, починаючи із сім'ї. На основі висловленого доходимо висновку, що ціннісні орієнтації відносять до найважливіших компонентів структури особистості, за ступенем сформованості яких можна бачити рівень сформованості особистості загалом.

\section{СПИСОК ЛІТЕРАТУРИ}

Андрущенко, В. \& Табачук, I. (2005). Формування особистості вчителя в сучасиих умовах. Політичний менеджмент, 1(10), 58-59.

Бех, I. (2003). Виховання особистості. Особистісно орієнтований підхід: теоретико-технологічні засади. Т.1. Київ : Либідь.

Волкова, Н. (2007). Педагогіка (2-ге вид.). Київ : Академвидав.

Вишневський, О. (1996). Сучасне українське виховання. Львів.

Вишневський, О. (2006). Теоретичні основи сучасної української педагогіки. Вид. 2, доопрацьоване і доповнене. Дрогобич.

Вітвицька, С. С. (2003). Основи педагогіки вищої школи. Київ : центр навч. літератури.

Григоренко, Л. О. (2005). Самостійна робота як фактор підвищення ефективності підготовки майбутніх педагогів до професійної діяльності. Рідна икола, 5, 22-23.

Гузій, Н. В. (2004). Педагогічний професіоналізм: історико-методологічні та теоретичні аспекти: монографія. Київ : НПУ імені М. П. Драгоманова.

Гузій, Н. В. (2004). Основи педагогічного професіоналізму. Київ : НПУ ім. М. П. Драгоманова.

Євтух, В. Б., Трощинський, В. Г., Галушко, К. Ю. \& Чернова, К. О. Етнонаціональна структура українського суспільства: довідник. (2004). Київ : Наукова думка.

Маркова, А. К. (1995). Психологические критерии и ступени профессионализма учителя. Педагогика, 6 , 55-68.

Мосіяшенко, В. А. (2005). Українсь- ка етнопедагогіка. Суми : ВТД "Університетська книга".

Бойко, А. М. (ред.). (2004). Педагогіка. Інтегрований курс теорії та історії. Київ : Полтава.

Зязюн, І. А. (2004). Педагогічна майстерність. 2-ге вид., допов. і перероб. Київ : Вища шк.

Золотарьова, О. (2012). Педагогічні передумови рішення проблеми формування ціннісних орієнтацій студентів. (ч. 1). Слов'янськ.

Стельмахович, М. Г. (1985). Народна педагогіка. Київ : Рад. шк.

Ткаченко, О. М. (2013). Теоретикометодичні засади формування етнопедагогічної компетентності майбутніх вчителів гуманітарного профілю. (Автореф. дис. ... д-ра пед. наук). Черкаський національний університет імені Богдана Хмельницького, Кіровоград.

Чорна, К. І. (1994). Основні пріоритети у вихованні національної самосвідомості і громадянської культури учнів. Педагогіка і психологія, 125-130.

Rusyn Halyna \& Yanyshyn Olha (2016). Competency-based approach in the process of modernization of institutes of higher education. Vocational trainiig some problems end contexts. Panstwowa wyzsza szkola zawodowa w Chelmie. Chelmskie towarzystwo naukowe.

\section{REFERENCES}

Andrushchenko, V., Tabachuk, I. (2005). Formation of teacher's personality in modern conditions. Political management, 1 (10), 58-59.

Beh, I. (2003). Educator of personality. A Personally Oriented Approach: Theoretical and Technological Foundations Vol.1. Kiev : Libid.

Volkova, N. (2007). Pedagogy: teach. tool. (2nd ed.). Kyiv : Academic Publishers.

Vishnevsky, O. (1996). Contemporary Ukrainian Education: Pedagogical Essays. Lviv.

Vishnevsky, O. (2006). Theoretical foundations of modern Ukrainian pedagogy. Drogobych.

Vitwitskaya, S.S. Fundamentals of Higher Education Pedagogy: Educ. tool. Kyiv: Training Center literature.

Grigorenko, L.O. (2005). Independent work as a factor in improving the effectiveness of training future teachers for professional activity Native School, 5, 22-23.

Hussey, N. W. (2004). Pedagogical Professionalism: Historical, Methodological and Theoretical Aspects: Monograph. Kiev : MP Drahomanov NPU.

Hussey, N. W. (2004). Fundamentals of pedagogical professionalism: Educ. manual. Kiev : NPU them. M.P. Drahomanov.

Yevtukh, V. B., Troshchynskyi, V. G., Galushko, K. Yu., Chernova, K. O. (2004). The Ethnonational Structure of Ukrainian Society: A Handbook Kiev: Scientific Opinion.

Markov, A. K. (1995). Psychological criteria and levels of teacher professionalism. Pedagogy, 6, 55-68.

Mosiashenko, VA(2005). Ukrainian Ethnopedagogy: Teach. tool. Amounts: VTD "University Book".

Boyko, A., Poltava, K. Pedagogy. An Integrated Theory and History Course: A Learning Method. tool. (2004). / per row A. M. Boyko. Kiev : Poltava.

Ziazun, I.A. Kramushchenko, L.V. Pedagogical Skills: Textbook Kiev: Higher School.

Zolotaryova, O. (2012). Pedagogical prerequisites for solving the problem of students' value orientations formation. Higher school Humanization of the educational process Special issue 6. Part 1 Sloviansk.

Stelmakhovich, MG (1985). Folk pedagogy. Kiev: Rad.shk ..

Tkachenko, O. M. (2013). Theoretical and methodological bases of formation of ethno-pedagogical competence of future teachers of the humanities profile. (abstract. Diss... Dr. Ped. of sciences). Bohdan Khmelnytsky Cherkasy National University. Kirovohrad.

Black, K. I. (1994). The main priorities in the education of national consciousness and civic culture of students. Pedagogy and Psychology, 1, 125-130.

Halyna Rusyn, Olha Yanyshyn (2016). Competency-based approach in the process of modernization of higher education institutes. Vocational trainiig some problems end contexts. Panstwowa wyzsza szkola zawodowa w Chelmie. Chelmskie towarzystwo naukowe.

Стаття надійшла 23.10.2019 p. 